\title{
Dampak Retribusi Jasa Umum Terhadap Pendapatan Asli Daerah Kabupaten Kuningan
}

\section{${ }^{1}$ Hadi Nuramin, ${ }^{2}$ Yendri Iqbal Fadilla}

\author{
${ }^{1}$ Sosiologi Fakultas Ilmu Sosial dan Ilmu Politik UIN Sunan Gunung Djati Bandung; \\ hadi_na@uinsgd.ac.id \\ ${ }^{2}$ Administrasi Publik Fakultas Ilmu Sosial dan Ilmu Politik UIN Sunan Gunung Djati Bandung; \\ yendriiqbalfadilla@gmail.com
}

\begin{abstract}
The target for public service levies is high every year but revenue realization is still far from the target. This shows the existence of fluctuations in revenue from general service levies on Kuningan's own-source revenue (PAD). This study aims to analyze the effect of public service levies on the original income of Kuningan Regency. The research approach used in this study is quantitative with an associative type of research. This research employed saturated sampling types. Techniques from data collection efforts were obtained through field research and library research. Based on the results of the hypothesis test, it appears that public service fees have a positive effect, amounting to 0.514 for an increase in local own-source revenue and in the quite high category. This means that between public service levies and local own-source revenue (PAD) have a fairly high (positive) relationship. If public service levies are higher, it will be followed by higher local own-source revenues.
\end{abstract}

Keywords: Local Government, Public Service Levies, The Region Own-Source Revenue

\section{Pendahuluan}

Otonomi daerah yang diterapkan pada tahun 2001 telah menjadi paradigma dalam penyelenggaraan dan penataan keuangan daerah dengan sangat mendasar. Prinsip utama pelaksanaan otonomi daerah untuk menjadi jalan yang lebih besar demi memaksimalkan potensi atau kemampuan daerah tersebut, berupa dana, sumber daya manusia, serta sumber daya lain berupa kekayaan daerah sebagaimana tercantum dalam UU No. 9 tahun 2015 tentang Pemerintahan Daerah (PEMDA) dan UU No. 33 Tahun 2004 tentang Perimbangan Keuangan Pemerintahan Pusat dengan Pemerintahan Daerah. Daerah dituntut untuk dapat melaksanakan kewenangan atau hak yang dimiliki karena sumber keuangan pemerintah pusat selalu dikaitkan dengan sumber keuangan daerah. Disinilah diperlukan adanya perbandingan yang transparan serta adil antara daerah dan pusat.

Keuangan daerah menurut Widjaja (2002:147) ialah segala kewajiban serta hak suatu daerah dalam upaya pelaksanaan pemerintahan daerah dalam bentuk potensi atau kekayaan lain berkaitan dengan kewajiban serta hak daerah tersebut dalam APBD yang bisa dinilai dengan uang. Sedangkan (Siregar, 2015:12) mengemukakan bahwai keuangan daerah ialah hak serta kewajiban. Segala bentuk berwujud uang ataupun barang yang dapat dipergunakan sebagai bentuk dari kekayaan suatu daerah selama belum dikuasai atau dimiliki oleh suatu daerah maupun negara yang memiliki kekuasaan yang lebih tinggi serta pihak lainnya sesuai peraturan perundangan atau ketentuan yang berlaku. Jadi keuangan daerah merupakan hak serta kewajiban suatu daerah dalam upaya pelaksanaan pemerintahan dimana bentuknya dapat dinilai maupun ternilai dengan uang yang bentuknya dapat berupa kekayaan daerah yang relevan dengan hak serta kewajiban yang tercantum di dalam APBD. Keuangan daerah 
menjadi tolak ukur bagi pemerintahan daerah dalam mengelola kekayaan daerah guna melangsungkan otonomi yang nyata, luas, dan bertanggung jawab

Pendapatan Asli Daerah (PAD) berdasarkan atas UU No. 33 Tahun 2004 tercantum bahwa perolehan penggunaan kekayaan daerah diperoleh dari retribusi daerah, pajak daerah, serta PAD lainnya yang dianggap sah berdasarkan aturan hukum yang berlaku. Dari ketiga sumber pendapatan tersebut, retribusi menjadi salah satu sumber yang dibahas dalam penelian ini. Adapun yang dimaksud dengan retribusi menurut PP No. 66 Tahun 2001 tentang Retribusi daerah yaitu diartikan sebagai suatu kewajiban atau beban yang secara langsung dibayar serta diberlakukan bagi pihak yang menggunakan segi pelayanan tertentu dari Pemerintah Daerah (PEMDA) yang tujuannya untuk menutup sebagian maupun keseluruhan biaya pelayanan tersebut. Menurut Mardiasmo (2013:12), Retribusi daerah didefinisikan sebagai suatu pungutan yang ditarik dari daerah guna pembayaran atas suatu jasa tertentu atau atas perizinan terentu.

Jadi, retribusi daerah merupakan pungutan oleh pemerintah daerah atas diberikannya jasa, atau izin tertentu kepada suatu badan maupun pribadi yang diperoleh dari pihak yang menggunakan pelayanan tersebut guna menutupi biaya-biaya yang dikeluarkan dalam memberikan pelayanan. Jenis retribusi daerah menurut UU No. 28 (2009) mengenai Pajak serta Retribusi Daerah yakni: retribusi jasa usaha, retribusi umum, serta retribusi perizinan. Terdapat 3 golongan dalam jenis retribusi daerah yaitu sebagai berikut (Mardiasmo, 2013:15):

1. Retribusi Jasa Umum terdiri dari :

a. Retribusi dalam bidang Uji Kapal Perikanan;

b. Retribusi dalam bidang Sampah atau Kebersihan;

c. Retribusi dalam bidang Kesehatan;

d. Retribusi dalam bidang Penggantian Biaya Cetak KTP dan Akte Capil;

e. Retribusi dalam bidang Pemeriksaan Alat Pemadam Kebakaran;

f. Retribusi dalam bidang Pemakaman dan Kremasi Mayat;

g. Retribusi dalam bidang Pasar;

h. Retribusi dalam bidang Ganti Uang Biaya Cetak Peta;

i. Retribusi dalam bidang Uji Motor; serta

j. Retribusi dalam bidang Parkir di Pinggir Jalanan Umum.

2. Retribusi Jasa Usaha terdiri dari :

a. Retribusi Aset Daerah;

b. Retribusi Pasar Grosir dan Pertokoan;

c. Retribusi Terminal;

d. Retribusi untuk Tempat Pelelangan;

e. Retribusi untuk Penempatan Parkir;

f. Retribusi untuk Pengolahan Limbah Cair;

g. Retribusi untuk Penginapan;

h. Retribusi untuk Tempat Liburan dan Olah Raga;

i. Retribusi untuk Penjualan Produk Daerah.

j. Retribusi untuk Pelayanan Pelabuhan Kapal;

k. Retribusi untuk Rumah Potong Hewani;

1. Retribusi untuk Penyeberangan di Atas Air; serta

m. Retribusi untuk Penyedotan Kakus. 
3. Retribusi Perizinan Tertentu terdiri dari :

a. Retribusi Gangguan;

b. Retribusi Trayek;

c. Retribusi Tempat Penjualan Alkohol; serta

d. Retribusi Mendirikan Bangunan.

Retribusi daerah merupakan sebuah pungutan terhadap suatu daerah sebagai wujud kompensasi yang didasarkan atas pemberian izin khusus maupun jasa tertentu terhadap suatu hal, serta mencakup segala sesuatu yang pemerintah daerah berikan untuk menunjang kebutuhan suatu badan maupun pribadi. Dari berbagai penerimaan sumber PAD tersebut, maka salah satu bagian dari penerimaan Pemerintah Daerah Kabupaten Kuningan yaitu retribusi daerah yang memberikan kontribusi besar serta merupakan sub sektor penerimaan daerah potensial guna diperluas serta dikembangkan. Berikut merupakan target serta realisasi retribusi daerah kabupaten Kuningan dari tahun 2013- 2017:

Tabel 1.1

Target dan Realisasi Retribusi Daerah Kabupaten Kuningan 2013-2017

\begin{tabular}{|c|c|c|c|}
\hline Tahun & $\begin{array}{c}\text { Target Retribusi } \\
\text { Daerah } \\
(\mathrm{Rp})\end{array}$ & $\begin{array}{c}\text { Realisasi Retribusi } \\
\text { Daerah } \\
(\mathrm{Rp})\end{array}$ & Persentase \\
\hline 2013 & 31.939 .821 .408 & 24.568 .808 .691 & $76,9 \%$ \\
\hline 2014 & 39.509 .004 .456 & 40.133 .135 .754 & $101,6 \%$ \\
\hline 2015 & 45.324 .227 .924 & 38.769 .625 .494 & $85,5 \%$ \\
\hline 2016 & 50.920 .300 .294 & 38.015 .060 .600 & $74,6 \%$ \\
\hline 2017 & 55.599 .365 .316 & 37.748 .101 .889 & $67,9 \%$ \\
\hline
\end{tabular}

Sumber: Data diolah dari BAPPENDA Kabupaten Kuningan, 2017

Dari tabel 1.1 data realisasi retribusi daerah Kabupaten Kuningan menghadapi ketidak stabilan setiap tahunnya, tahun 2014 menjadi realisasi tertinggi sebesar Rp. 40.133.135.754 dan realisasi terendah terdapat pada tahun 2013 sebesar Rp. 24.568.808.691. Pertumbuhan tahun 2013-2014 adalah mengalami kenaikan sebesar Rp. 15.564.327.063 atau 38,78\%. Lalu untuk pertumbuhan tahun 2014-2015 adalah mengalami penurunan sebesar Rp. 1.363.510.260 atau 3,39\%. Sedangkan untuk perkembangan tahun 2015-2016 adalah mengalami penurunan sebesar Rp. 754.564.894 atau 1,94\% dan pertumbuhan tahun 20162017 mengalami penurunan sebesar Rp. 266.958.711 atau 0,7\%.

Potensi Kabupaten Kuningan yang baik dalam ranah kuliner, pariwisata, serta hiburan membuat Pemerintah Kabupaten Kuningan atau pihak swasta sangat mengusahakan dalam jasa umum. Swalayan serta pertokoan yang semakin berkembang menggambarkan peningkatan dalam daya beli masyarakat Kabupaten Kuningan. Jasa umum di Kabupaten Kuningan sangat berpotensi dalam peningkatan PAD dilihat dari jumlah jasa umum yang dimiliki. Perolehan retribusi jasa umum merupakan kontributor paling besar dalam perolehan retribusi daerah diluar retribusi perizinan tertentu serta retribusi jasa usaha. Data ini didasarkan pada data lima tahun terakhir. Sementara itu, tujuan Kabupaten Kuningan yang 
ingin dicapai serta realisasi retribusi jasa umum dari tahun 2013-2017 dapat dijabarkan sebagai berikut:

\section{Tabel 1.2}

Target dan Realisasi Retribusi Jasa Umum Kabupaten Kuningan 2013-2017

\begin{tabular}{|c|c|c|c|}
\hline Tahun & $\begin{array}{c}\text { Realisasi } \\
\text { Retribusi Jasa } \\
\text { Umum (Rp) }\end{array}$ & $\begin{array}{c}\text { Realisasi } \\
\text { Retribusi Jasa } \\
\text { Usaha (Rp) }\end{array}$ & $\begin{array}{c}\text { Retribusi Perizinan } \\
\text { Tertentu (Rp) }\end{array}$ \\
\hline 2013 & 20.865 .977 .002 & 1.914 .645 .008 & 1.788 .186 .681 \\
\hline 2014 & 36.343 .649 .733 & 1.731 .436 .154 & 2.058 .049 .867 \\
\hline 2015 & 35.122 .746 .171 & 1.771 .005 .064 & 1.875 .874 .259 \\
\hline 2016 & 34.017 .249 .448 & 1.591 .477 .430 & 2.406 .333 .722 \\
\hline 2017 & 32.109 .958 .474 & 1.604 .236 .273 & 4.033 .907 .142 \\
\hline
\end{tabular}

Sumber: Data diolah dari BAPPENDA Kabupaten Kuningan, 2017

Dari tabel 1.2 data realisasi retribusi jasa umum Kabupaten Kuningan menghadapi ketidakstabilan setiap tahunnya, tahun 2014 menjadi realisasi tertinggi sebesar Rp. 36.343.649.733 dan realisasi terendah terdapat pada tahun 2013 sebesar Rp. 20.865.977.002. Pertumbuhan tahun 2013-2014 adalah mengalami kenaikan sebesar Rp. 15.477.672.731 atau 42,58\%. Lalu untuk pertumbuhan tahun 2014-2015 adalah mengalami penurunan sebesar Rp. 1.220.903.562 atau 3,35\%. Sedangkan untuk perkembangan tahun 2015-2016 adalah mengalami penurunan sebesar Rp. 1.105.496.723 atau 3,14\% dan pertumbuhan tahun 20162017 mengalami penurunan sebesar Rp. 1.907.290.974 atau 5,6\%. Pertumbuhan pada tahun 2013-2014 menjadi satu-satunya kenaikan yang terjadi berdasarkan data lima tahun terakhir. Namun kontributor yang paling baik dalam perolehan Retribusi Daerah tetap dipegang oleh Retribusi Jasa Umum.

\section{Metode Penelitian}

Metode penelitian ialah langkah ilmiah atau rasional dalam memperoleh data dengan manfaat dan tujuan tertentu (Anggara, 2015:14). Penelitian yang dilakukan kali ini termasuk ke dalam penelitian yang jenisnya bersifat asosiatif serta menggunakan pendekatan kuantitatif dalam metode penelitiannya. Selanjutnya Sugiyono (2017:8) mengatakan bahwa yang dimaksud dengan jenis kuantitatif ialah yang memiliki landasan atas filsafat positivisme dan umumnya dipergunakan untuk meneliti suatu sampel maupun populasi tertentu, pengumpulan data dikumpulkan dengan melalui berbagai cara seperti analisis data dan instrumen penelitian, baik yang sifatnya statistik maupun yang sifatnya kuantitatif dengan maksud tujuan yang yaitu guna melakukan suatu pengujian terhadap hipotesis yang sebelumnya telah ditentukan. Berdasarkan variabel-variabel yang diteliti, retribusi jasa umum merupakan variabel $\mathrm{X}$ dan pendapatan asli daerah merupakan variabel $\mathrm{Y}$. Selanjutya data yang digunakan yaitu laporan rekapitulasi target dan realisasi pendapatan kabupaten Kuningan tahun 2013-2017. 


\section{Hasil Dan Pembahasan}

\section{a. Uji Asumsi Klasik}

Jenis uji dilakukan sebelum pembentukan model regresi yang ditujukan agar model yang terbentuk kelak dapat memberikan estimasi yang positif, maka dalam hal ini digunakanlah suatu jenis pengujian yang dilakukan yaitu atas dasar uji normalitas.

Uji Normalitas

Di bawah ini disajikan suatu table hasil output dari program SPSS 23.00 uji normalitas dengan jenis pengujian uji Kolmogorov-Smirnov.

\section{Tabel $\quad 3.1$}

Uji Normalitas

One-Sample Kolmogorov-Smirnov Test

\begin{tabular}{|ll|r|}
\hline & & $\begin{array}{r}\text { Unstandardiz } \\
\text { ed Residual }\end{array}$ \\
\hline $\mathrm{N}$ & Mean &,- 0000597 \\
Normal & Std. &, 00003883 \\
Parameters & a,b & Deviation \\
Most Extreme & Absolute &, 252 \\
Differences & Positive &, 252 \\
& Negative &,- 174 \\
Test Statistic & &, 252 \\
Asymp. Sig. (2-tailed) &, $200^{\mathrm{c}, \mathrm{d}}$ \\
\hline
\end{tabular}

a. This is a lower bound of the true significance;

b. Test distribution is Normal;

c. Calculated from data;

d. Lilliefors Significance Correction.

Diperoleh suatu nilai dari uji Kolmogorov-Smirnov sebesar 0,252 sebesar sig= $0,200^{c, d}$. Karena nilai sig. $>0,05$ (disimpulkan bahwa residual data berdistribusi normal).

b. Uji Hipotesis

Pengaruh Retribusi Jasa Umum Terhadap Pendapatan Asli Daerah di Kabupaten Kuningan Periode $2013-2017$

\section{Analisis Regresi Linier Sederhana}

Model regresi linier sederhana yang akan dibentuk adalah sebagai berikut:

$$
\mathrm{Y}=\alpha+\mathrm{bx}
$$


Dimana:

$\mathrm{Y}=$ Pendapatan Asli Daerah

$\mathrm{X}=$ Retribusi Jasa Umum

$\alpha=$ Bilangan konstanta

Dengan menggunakan program SPSS 23.00 for Windows, diperoleh hasil koefisien regresi sebagai berikut:

Tabel 3.2

\section{Persamaan Regresi}

\begin{tabular}{|c|c|c|c|c|c|}
\hline \multicolumn{6}{|c|}{ Coefficients ${ }^{a}$} \\
\hline \multirow[b]{2}{*}{ Model } & \multicolumn{2}{|c|}{$\begin{array}{l}\text { Unstandardized } \\
\text { Coefficients }\end{array}$} & \multirow{2}{*}{$\begin{array}{c}\text { Standar } \\
\text { dized } \\
\text { Coeffic } \\
\text { ients } \\
\text { Beta }\end{array}$} & \multirow[b]{2}{*}{$\mathrm{t}$} & \multirow[b]{2}{*}{ Sig. } \\
\hline & $\mathrm{B}$ & Std. Error & & & \\
\hline $1 \quad$ (Constant) & $\begin{array}{r}196830509 \\
58,201\end{array}$ & $\begin{array}{r}25097053 \\
0939,526\end{array}$ & &,- 078 & ,942 \\
\hline $\begin{array}{l}\text { Retribusi } \\
\text { Jasa Umum }\end{array}$ & 8,084 & 7,799 & ,514 & 1,037 & ,376 \\
\hline
\end{tabular}

a. Dependent Variabel: Pendapatan Asli Daerah

Berdasarkan analisa atas hasil output di atas maka dapat diketahui diketahui nilai konstanta serta koefisien regresi yang kemudian dapat dibentuk persamaan regresi linier sederhana sebagai berikut:

$$
Y=-19683050958,201+8,084 X
$$

Persamaan di atas dapat diartikan sebagai berikut:

$\alpha=-19683050958,201$ artinya jika variabel $\mathrm{X}$ bernilai nol (0), maka variabel Y akan bernilai -19683050958,201 satuan.

$\mathrm{b}=8,084$ artinya jika Retribusi Jasa Umum meningkat sebesar satu satuan dan variabel lainnya konstan, maka variabel Y akan meningkat sebesar 8,084 satuan.

c. Analisis Korelasi

Analisis korelasi dimaksudkan untuk mengetahui kekuatan hubungan (asosiasi) linier antara dua variabel. Analisis korelasi tidak menunjukan adanya suatu keterkaitan yang bersifat fungsional, atau dengan kata lain analisis tersebut tidak memisahkan ataupun membedakan antara variabel terikat dengan variabel bebasnya. Adapun dalam analisis regresi sendiri, analisis korelasi yang dipergunakan akan menunjukan pula arah dari hubungan antara variabel terikat dengan variabel bebas ihwal daripada kegiatan pengukuran kekuatan hubungannya (asosiasi). 
Untuk menghitung korelasi secara parsial antara X (Retribusi Jasa Umum) dengan Y (Pendapatan Asli Daerah) cara yang dipergunakan oleh peneliti guna usaha untuk mendapatkan hasil dari korelasi person ialah dengan menggunakan perhitungan melalui SPSS 23.00 for windows, maka didapatkan hasil korelasi seperti tabel berikut ini:

Tabel 3.3

\section{Hasil Korelasi Parsial Retribusi Jasa Umum dengan Pendapatan Asli Daerah}

Correlations

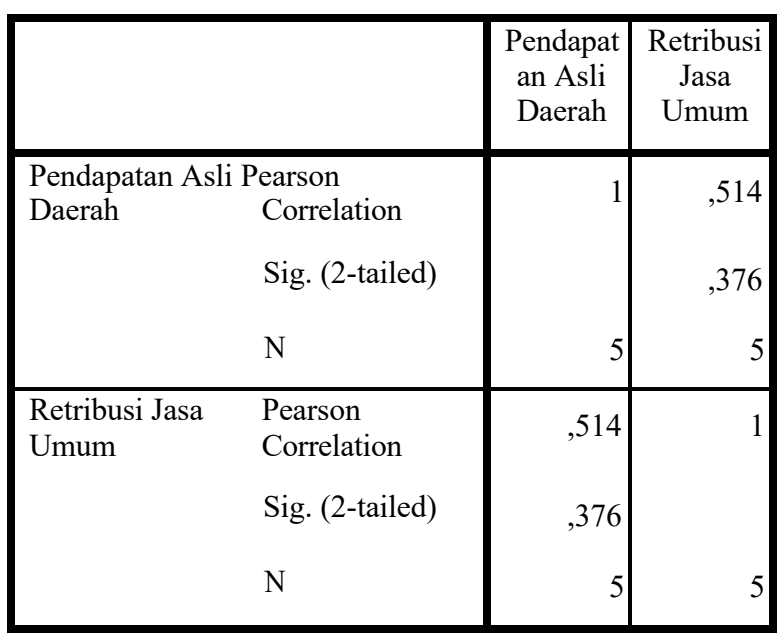

Nilai korelasi yang diperoleh antara Retribusi Jasa Umum dengan Pendapatan Asli Daerah apabila yaitu sebesar 0,514 serta dapat dipastikan masuk dalam kategori yang cukup kuat. Jadi, antara kedua variabel terjadi hubungan berbanding lurus (positif) yang cukup kuat. Jika Retribusi Jasa Umum semakin melambung tinggi maka akan diikuti oleh Pendapatan Asli Daerah yang akan menjadi semakin melambung tinggi pula.

\section{d. Pengujian Hipotesis Parsial (Uji t)}

Digunakan program SPSS 23.00 for windows, hasil output nya seperti di bawah ini:

Tabel $\quad 3.4$

Uji T (Parsial)

Coefficients $^{\mathrm{a}}$

\begin{tabular}{|c|c|c|c|c|c|}
\hline \multirow[b]{2}{*}{ Model } & \multicolumn{2}{|c|}{$\begin{array}{l}\text { Unstandardized } \\
\text { Coefficients }\end{array}$} & \multirow{2}{*}{$\begin{array}{l}\text { Stand } \\
\text { ardiz } \\
\text { ed } \\
\text { Coeff } \\
\text { icient } \\
\mathrm{s} \\
\text { Beta }\end{array}$} & \multirow[b]{2}{*}{$\mathrm{t}$} & \multirow[b]{2}{*}{ Sig } \\
\hline & B & $\begin{array}{l}\text { Std. } \\
\text { Error }\end{array}$ & & & \\
\hline $\begin{array}{c}1 \text { (Constant } \\
\text { ) }\end{array}$ & $\begin{array}{r}1968305 \\
0958,20 \\
1\end{array}$ & $\begin{array}{r}2509705 \\
30939,5 \\
26\end{array}$ & & $\begin{array}{r}- \\
, 0 \\
78\end{array}$ & $\begin{array}{r}, 94 \\
2\end{array}$ \\
\hline $\begin{array}{l}\text { Retribusi } \\
\text { Jasa } \\
\text { Umum }\end{array}$ & 8,084 & 7,799 & ,514 & $\begin{array}{r}1, \\
03 \\
7\end{array}$ & $\begin{array}{r}, 37 \\
6\end{array}$ \\
\hline
\end{tabular}

a. Dependent Variabel: Pendapatan Asli Daerah 
Pengujian hipotesis terhadap variabel X (Retribusi Jasa Umum)

$\mathrm{H}_{0} \quad$ : Retribusi Jasa Umum ada pengaruh signifikan terhadap pendapatan asli daerah (PAD).

$\mathrm{H}_{1} \quad$ : Ada pengaruh Retribusi Jasa Umum yang cukup signifikan terhadap pendapatan asli daerah (PAD).

Adapun tingkat signifikan $(\alpha)$ yaitu sebesar $5 \%$, serta derajat kebebasan $(v)=3=(n-$ $(\mathrm{k}+1))$ maka diperoleh nilai $\mathrm{t}_{\text {tabel }} 3,182$.

Dari hasil output SPSS di atas maka diperoleh suatu nilai $t_{\text {hitung }}$ untuk $X$ yang besarnya 1,037 dan $t_{\text {tabel }} 3,182$. Disebabkan karena nilai $t_{\text {hitung }}<t_{\text {tabel }}$, maka $\mathrm{H}_{0}$ diterima, yang artinya tidak ada pengaruh yang signifikan atas Retribusi Jasa Umum terhadap pendapatan asli daerah (PAD).

e. Analisis Koefisien Determinasi

Kemudian ketika telah diketahui besar nilai $\mathrm{R}$ 0,514 maka dari itu koefisien determinasi sendiri dapat dihitung melalui suatu rumus:

Tabel

3.5

\section{Koefisien Determinasi}

Model Summary

\begin{tabular}{|l|r|r|r|r|}
\hline Model & \multicolumn{1}{|c|}{$\mathrm{R}$} & R Square & $\begin{array}{c}\text { Adjusted R } \\
\text { Square }\end{array}$ & $\begin{array}{r}\text { Std. Error } \\
\text { of the } \\
\text { Estimate }\end{array}$ \\
\hline 1 &, $514^{\mathrm{a}}$ &, 264 &, 018 & $\begin{array}{r}974659475 \\
01,553\end{array}$ \\
\hline
\end{tabular}

$\mathrm{KD}=\mathrm{R}^{2} \mathrm{X} 100 \%$

$$
\begin{aligned}
& =(0,514)^{2} \times 100 \% \\
& =26,4 \%
\end{aligned}
$$

Oleh sebab itu, maka dapat diperoleh nilai KD sebesar $26,4 \%$ yang artinya menunjukan bahwa Retribusi Jasa Umum berkontribusi atas pengaruh yang besarnya 26,4\% terhadap pendapatan asli daerah (PAD). Adapun sisa yang besarnya 73,6\% medapatkan pengaruh dari faktorr-faktor lain yang dihiraukan oleh penulis.

1. Pengaruh Dimensi-Dimensi Retribusi Jasa Umum Terhadap Pendapatan Asli Daerah Di Kabupaten Kuningan Secara Parsial

Berikut ini beberapa dimensi retribusi jasa umum yang mempengaruhi Pendapatan Asli Daerah di Kabupaten Kuningan Secara Parsial, yaitu:

a. Pengaruh Retribusi Pelayanan Kesehatan/Dinas Kesehatan Terhadap Pendapatan Asli Daerah di Kabupaten Kuningan Periode 2013-2017

Berdasarkan hasil pengujian koefisien regresi retribusi pelayanan kesehatan/dinas kesehatan memperoleh nilai sebesar -16,456, artinya jika Retribusi Pelayanan kesehatan/dinas kesehatan meningkat -16,456 maka pendapatan asli daerah akan menurun 16,456. Sedangkan berdasarkan hasil pengujian parsial, retribusi pelayanan kesehatan/dinas 
kesehatan akan pendapatan asli daerah (PAD) Kabupaten Kuningan tahun 2013-2017 diperoleh suatu nilai $t_{\text {hitung }}(-1,365)<t_{\text {tabel }}(3,182)$ dengan taraf signifikansi $0,266>0,05$ yang kemudian dapat disimpulkan bahwa $\mathrm{H}_{0}$ diterima. Maka dapat diartikan bahwasannya tidak adanya suatu pengaruh yang signifikan retribusi pelayanan kesehatan/dinas kesehatan akan pendapatan asli Daerah (PAD) Kabupaten Kuningan tahun 2013-2017. Hal tersebut diindikasikan karena penerimaan retribusi pelayanan kesehatan/dinas kesehatan selalu kecil dan mengalami fluktuasi pendapatan karena Pemerintah Kabupaten Kuningan belum mampu melaksanakan retribusi pelayanan kesehatan/dinas kesehatan secara optimal.

b. Pengaruh Retribusi Pelayanan Kesehatan/RSUD Linggarjati Terhadap Pendapatan Asli Daerah di Kabupaten Kuningan Periode 2013 - 2017

Berdasarkan hasil pengujian koefisien regresi retribusi pelayanan kesehatan/RSUD Linggarjati memperoleh nilai sebesar 10,914, artinya jika retribusi pelayanan kesehatan/RSUD Linggarjati meningkat 10,914 maka pendapatan asli daerah akan meningkat 10,914. Sedangkan hasil pengujian parsial, retribusi pelayanan kesehatan/RSUD Linggarjati akan pendapatan asli daerah (PAD) Kabupaten Kuningan tahun 2013-2017 diperoleh suatu nilai $t_{\text {hitung }}(2,339)<t_{\text {tabel }}(3,182)$ dengan jumlah taraf signifikansi yaitu sebesar $0,101>0,05$ maka $\mathrm{H}_{0}$ diterima. Dapat pula diartikan bahwa tidak ditemukannya suatu pengaruh yang signifikan retribusi pelayanan kesehatan/RSUD Linggarjati atas pendapatan asli Daerah (PAD) Kabupaten Kuningan tahun 2013-2017. Hal tersebut diindikasikan karena penerimaan retribusi pelayanan kesehatan/RSUD Linggarjati selalu menurun dan mengalami fluktuasi pendapatan karena Pemerintah Kabupaten Kuningan belum mampu melaksanakan retribusi pelayanan kesehatan/RSUD Linggarjati secara optimal.

c. Pengaruh Retribusi Pelayanan Kebersihan atau Persampahan akan Pendapatan Asli Daerah (PAD) di Kabupaten Kuningan berdasarkan Periode tahun 2013 - 2017

Berdasarkan hasil pengujian koefisien regresi retribusi pelayanan persampahan/kebersihan memperoleh nilai sebesar 3009,692, artinya jika retribusi sampah dan kebersihan meningkat 3009,692 maka pendapatan asli daerah akan meningkat 3009,692. Sedangkan hasil pengujian parsial, retribusi pelayanan kebersihan atau persampahan akan pendapatan asli daerah (PAD) Kabupaten Kuningan periode 2013-2017 diperoleh jumlah nilai thitung $(8,935)>$ ttabel $(3,182)$ dengan hasil taraf signifikansi terbilang $0,003<0,05$ yang artinya dapat ditarik suatu benang merah bahwa H0 dipastikan ditolak. Dengan demikian, terdapat adanya suatu pengaruh yang signifikan anatara retribusi pelayanan kebersihan atau persampahan akan pendapatan asli Daerah (PAD) Kabupaten Kuningan periode 2013-2017. Hal tersebut diindikasikan karena penerimaan retribusi retribusi pelayanan persampahan/ kebersihan selalu naik. Hal ini mungkin karena retribusi pelayanan persampahan/ kebersihan merupakan sektor yang diutamakan dan terus dikelola serta dimanfaaatkan sampahnya, sehingga penerimaan retribusi pelayanan persampahan/ kebersihan setiap tahunnya sudah mampunya meningkatkan pendapatan asli dari daerah (PAD).

d. Pengaruh Retribusi Tempat Parkir di Tepi Jalan Umum/Ret. Parkir Terhadap Pendapatan Asli Daerah di Kabupaten Kuningan Periode 2013 - 2017

Berdasarkan hasil pengujian koefisien regresi retribusi terhadap tempat parkiryang berada di tepi jalan umum atau retribusi parkir maka diperoleh nilai yang besarnya 621,574, artinya jika retribusi parkir dipastikan meningkat 621,574 maka pendapatan asli daerah (PAD) juga meningkat sebesar 621,574. Sedangkan hasil pengujian parsial, retribusi parkir 
atau retribusi tempat parkir yang bertempat di tepi jalan umum atau terhadap pendapatan asli daerah Kabupaten Kuningan tahun periode 2013-2017 diperoleh sejumlah nilai thitung $(2,703)$ $<\mathrm{t}_{\text {tabel }}(3,182)$ dengan perbandingan taraf signifikansi sebesar $0,074>0,05$ maka $\mathrm{H}_{0}$ diterima. Jadi dapat ditarik suatu benang merah bahwa dipastikan tidak adanya pengaruh yang signifikan retribusi tempat parkir terhadap pendapatan asli Daerah (PAD) Kabupaten Kuningan tahun 2013-2017. Hal tersebut diindikasikan karena penerimaan retribusi tempat parkir di tepi jalan umum atau retribusi parkir belum cukup baik karena Pemerintah Kabupaten Kuningan belum mampu melaksanakan retribusi tempat parkir di tepi jalan umum atau retribusi parkir secara optimal.

e. Pengaruh Retribusi Pelayanan Pasar Terhadap Pendapatan Asli Daerah di Kabupaten Kuningan Periode 2013 - 2017

Berdasarkan hasil pengujian koefisien regresi retribusi pasar memperoleh nilai sebesar $-1133,220$, artinya jika retribusi pasar meningkat -1133,220 maka pendapatan asli daerah akan menurun 1133,220. Sedangkan berdasarkan hasil dari pengujian parsial, retribusi pasar atas jumlah pendapatan asli daerah (PAD) Kabupaten Kuningan periode 2013-2017 diperoleh sejumlah nilai $t_{\text {hitung }}(2,358)<t_{\text {tabel }}(3,182)$ dengan perbandingan taraf signifikansi sebesar $0,100>0,05$ maka $\mathrm{H}_{0}$ dapat diterima. Jadi, tidak ditemukan adanya suatu pengaruh yang signifikan antara retribusi pasar atas pendapatan asli Daerah (PAD) Kabupaten Kuningan tahun periode 2013-2017. Hal tersebut diindikasikan karena penerimaan retribusi pasar selalu kecil dan mengalami fluktuasi pendapatan karena Pemerintah Kabupaten Kuningan belum mampu melaksanakan retribusi pasar secara optimal.

f. Pengaruh Retribusi Pengujian Kendaraan Bermotor (PKB) Terhadap Pendapatan Asli Daerah di Kabupaten Kuningan Periode 2013 - 2017

Berdasarkan hasil pengujian koefisien regresi retribusi uji kendaraan bermotor memperoleh nilai sebesar -8221,406, artinya jika retribusi tersebut meningkat -8221,406 maka pendapatan asli daerah akan menurun 8221,406 . Sedangkan hasil pengujian parsial, retribusi uji kendaraan bermotor terhadap pendapatan asli dari daerah di Kabupaten Kuningan periode 2013-2017 diperoleh suatu nilai $t_{\text {hitung }}(0,770)<t_{\text {tabel }}(3,182)$ dengan jumlah perbandingan taraf signifikansi 0,498 >0,05 maka dipastikan $\mathrm{H}_{0}$ dapat diterima. Dengan demikian, tidak terdapat ditemukan adanya suatu pengaruh yang dinilai signifikan terhadap retribusi uji kendaraan bermotor atas pendapatan asli Daerah di Kabupaten Kuningan periode 2013-2017. Hal tersebut diindikasikan karena penerimaan retribusi pengujian kendaraan bermotor (PKB) selalu kecil dan mengalami fluktuasi pendapatan karena Pemerintah Kabupaten Kuningan belum mampu melaksanakan retribusi atas pengujian terhadap kendaraan bermotor (PKB) secara optimal.

g. Pengaruh Retribusi terhadap Pemeriksaan Pemadam Kebakaran atas Pendapatan Asli Daerah (PAD) di Kabupaten Kuningan tahun Periode 2013 - 2017

Berdasarkan hasil pengujian koefisien regresi retribusi pemeriksaan pemadam kebakaran memperoleh nilai sebesar 107593,128, artinya jika retribusi retribusi pemeriksaan pemadam kebakaran meningkat 107593,128 maka pendapatan asli daerah akan meningkat 107593,128. Sedangkan hasil pengujian parsial, retribusi pemeriksaan pemadam kebakaran atas pendapatan asli dari daerah di Kabupaten Kuningan tahun periode 2013-2017 menunjukan hasil nilai thitung $(5,520)>t_{\text {tabel }}(3,182)$ dengan perbandingan taraf signifikansi sejumlah $0,012<0,05$ maka $\mathrm{H}_{0}$ dipastikan ditolak. Dengan demikian, terdapat suatu pengaruh yang cukup signifikan terhadap retribusi pemeriksaan pemadam kebakaran atas 
pendapatan asli Daerah Kabupaten Kuningan tahun periode 2013-2017. Hal tersebut diindikasikan karena penerimaan retribusi pemeriksaan pemadam kebakaran stabil. Hal ini mungkin karena retribusi pelayanan persampahan/kebersihan merupakan sektor yang diutamakan karena berhubungan dengan keselematan, sehingga penerimaan retribusi pemeriksaan pemadam kebakaran setiap tahunnya sudah mampunya meningkatkan pendapatan asli daerah.

h. Pengaruh Retribusi Jasa Pelatihan Swadana / Pelayanan Pendidikan Terhadap Pendapatan Asli Daerah di Kabupaten Kuningan Periode 2013 - 2017

Berdasarkan hasil pengujian koefisien regresi retribusi jasa pelatihan swadana/pelatihan pendidikan memperoleh nilai sebesar 61672,742 , artinya jika retribusi jasa pelatihan swadana/pelatihan pendidikan meningkat 61672,742 maka pendapatan asli daerah akan meningkat 61672,742. Sedangkan hasil pengujian parsial, retribusi jasa pelatihan swadana/pelatihan pendidikan atas pendapatan asli dari daerah (PAD) Kabupaten Kuningan tahun 2013-2017 diperoleh suatu nilai thitung $(2,308)<t_{\text {tabel }}(3,182)$ dengan taraf perbandingan signifikansi $0,104>0,05$ maka $\mathrm{H}_{0}$ dinyatakan diterima. Jadi, tidak ditemukan adanya suatu pengaruh yang signifikan retribusi jasa pelatihan swadana/pelatihan pendidikan atas pendapatan asli dari daerah (PAD) Kabupaten Kuningan tahun 2013-2017. Hal tersebut diindikasikan karena penerimaan retribusi jasa pelatihan swadana/pelatihan pendidikan belum cukup baik dan mengalami fluktuasi pendapatan karena Pemerintah Kabupaten Kuningan belum mampu melaksanakan retribusi jasa pelatihan swadana/pelatihan pendidikan secara optimal.

2. Pengaruh Dimensi-Dimensi Retribusi Jasa Umum Terhadap Pendapatan Asli Daerah Di Kabupaten Kuningan Secara Simultan

Koefisien regresi variabel retribusi jasa umum dari hasil pengujian regresi memperoleh nilai sebesar 8,084, artinya bahwa jika Retribusi jasa umum dinaikan maka akan diperoleh kenaikan jumlah pendapatan asli daerah sebesar 8,084. Sedangkan berdasarkan hasil pengujian parsial, retribusi jasa umum terhadap pendapatan asli daerah di Kabupaten Kuningan Tahun 2013-2017 diperoleh nilai $t_{\text {hitung }}(1,037)<t_{\text {tabel }}(3,182)$ dengan taraf perbandingan signifikansi 0,376 $>0,05$ maka $\mathrm{H} 0$ dipastikan diterima diterima. Dengan demikian, tidak ditemukan adanya suatu pengaruh yang signifikan retribusi jasa umum atas pendapatan asli di daerah Kabupaten Kuningan Tahun 2013-2017. Hal tersebut diindikasikan karena penerimaan retribusi jasa umum selalu mengalami fluktuasi pendapatan dan banyak realisasi retribusi jasa umum yang tidak mencapai target karena Pemerintah Kabupaten Kuningan belum mampu menggali retribusi jasa umum secara optimal.

Hasil pengujian secara parsial pun sesuai hasilnya sama sebagaimana penelitian yang telah dilakukan sebelumnya oleh Eka Putriani (2016) yang hasilnya tidak ada pengaruh yang signifikan antara Retribusi daerah dengan pendapatan asli dari daerah. Namun, meskipun hasil yang dipeoleh menatakan tidak adanya keterkaitan secara signifikan, akan tetapi hal tersebut tidak lantas berarti bahwa government dapat menghiraukan retribusi jasa umum. Tetapi sebaiknya pemerintah daerah harus terus berkonsentrasi untuk terus dapat mengelola dan menggali retribusi jasa umum dengan baik, karena bagaimanapun retribusi jasa umum merupakan kontributor terbesar dalam retribusi daerah sehingga berpotensi dalam meningkatkan pendapatan asli daerah. 


\section{Simpulan}

Berdasarkan pada hasil analisis dan pembahasan penelitian ini, maka dapat diismpulkan bahwa:

1. Dari hasil uji hipotesis dapat disimpulkan sebagai berikut:

a. Dimensi-dimensi yang berpengaruh signifikan

1) Retribusi atas pelayanan persampahan/kebersihan

2) Retribusi atas pemeriksaan pemadam kebakaran

b. Dimensi-dimensi yang tidak bepengaruh signifikan

1) Retribusi atas pelayanan kesehatan/dinas kesehatan

2) Retribusi atas pelayanan kesehatan/RSUD Linggarjati

3) Retribusi atas tempat parkir di jalan umum

4) Retribusi atas pasar

5) Retribusi atas uji terhadap motor

6) Retribusi atas jasa untuk pelatihan swadana/pelatihan pendidikan

2. Dari hasil uji tersebut, dengan demikian dapat ditarik suatu benang merah atau kesimpulan bahwa variabel retribusi jasa umum tidak memiliki pengaruh yang signifikan atas pendapatan asli di daerah (PAD) yang ada di Kabupaten Kuningan untuk Tahun 2013 sampai dengan 2017.

\section{Referensi}

Abuyamin, O. (2012). Perpajakan Pusat dan Daerah. Bandung: Humaniora.

Anggara, S. (2015). Metode Penelitian Administrasi. Bandung: CV Pustaka Setia.

Ghozali, I. (2016). Aplikasi Analisis Multivariaete Dengan Program IBM SPSS 23. Semarang: Universitas Diponegoro.

Gie, T.L. (1992). Administrasi Perkantoran Modern, Edisi Keempat. Yogyakarta: Liberti bersama dengan Yayasan Studi Ilmu dan Teknologi.

Hernandez, J.V., Noruzi, M.R., Ali, I.F.N.H. (2011). What is Policy, Social Policy and Social Policy Changing?. International Journal of Business and Social Science. 2011. 2 (10). pp.287-291.

Kurniawan, P., dan Purwanto, A. (2004). Pajak Daerah \& Retribusi Daerah di INDONESIA. Malang: Bayumedia Publishing

Lakoy, T.W., Engka, D.S.M., Tumangkeng, S.Y.L. (2016). Kontribusi dan Pengaruh Penerimaan Retribusi Daerah Terhadap Pendapatan Asli Daerah di Kabupaten Minahasa Selatan (2005-2014). Jurnal Berkala Ilmiah Efisiensi. 2016. 16 (1). Hal. 559-567. https://ejournal.unsrat.ac.id/index.php/jbie/article/view/11067/10656 (diakses pada 20 Februari 2019).

Liu, J., Hu, X., and Tang, T. (2019). Fiscal Decentralization and Regional Financial Efficiency: An Empirical Analysis of Spatial Durbin Model. Hindawi Publishing Corporation Discrete Dynamics in Nature and Society. 2016. Pages 1-14. Available at: http://dx.doi.org/10.1155/2016/6597138 (diakses pada 20 Februari 2019). 
Mardiasmo. (2013). Perpajakan Edisi Revisi. Yogyakarta: Andi Offset.

Marume, S. B. M., Ndudzo, D. Public Financial Administration. International Journal of Business and Management Invention. 2016. 5 (6). PP—95-107. Available at: https://www.ijbmi.org/papers/Vol(5)6/M05060950107.pdf (diakses pada 20 Februari 2019).

Mulyawan, R., Enceng. (2016). Administrasi Keuangan Edisi Ketiga. Tanggerang: Universitas terbuka.

Najmuddin, C.F. (2018). Pengaruh Pajak Daerah dan Retribusi Daerah Terhadap Kemandirian Keuangan Daerah Kabupaten Sumedang Tahun 2012-2017. Skripsi.

Ningsih, H.T.K.(2017). The Effect of Regional Tax and Regional Retribution on Regional Expenditure in Local Governments of North Sumatera Province. Proceedings of The 7th Annual International Conference (AIC) Syiah Kuala University and The 6th International Conference on Multidisciplinary Research (ICMR) in conjunction with the International Conference on Electrical Engineering and Informatics (ICELTICs) 2017. 2017. pp.220-227. Available at: http://www.jurnal.unsyiah.ac.id/AICS-Social/article/view/10194/8647 (diakses pada 25 Februari 2019).

Nurcholis, H. (2005). Teori dan Praktik Pemerintahan dan Otonomi Daerah. Jakarta: PT. Grasindo.

Paramasivan, C dan T. Subramania. (2009). Financial Management. Salem: New Age InternasionalPublisher. http://vcmdrp.tums.ac.ir/files/financial/istgahe_mali/moton_english/financial_manage ment_\%5Bwww.accfile.com\%5D.pdf (diakses pada 20 Februari 2019).

Putriani. E. (2016). Pengaruh Retribusi Daerah Terhadap Pendapatan Asli Daerah Kabupaten Bulukumba Tahun 2006-2015. Skripsi

Pasolong, H. (2014). Teori Administrasi Publik. Bandung: Alfabeta

Siagian, S.P. (2008). Filsafat Administasi. Jakarta: Gunung Agung.

Silalahi, U. (2012). Metode Penelitian Sosial. Bandung: Aditama.

Siregar, B. (2015). Akuntansi Sektor Publik. Yogyakarta: UPP STIM YKPN.

Sugiyono. (2013). Metode Penelitian Administrasi. Bandung: Alfabeta.

Sugiyono. (2017). Metode Penelitian Kuantitatif, Kualitatif dan R\&D. Bandung: Alfabeta.

Suyatna, U. (2011). Keuangan Negara. Bandung: Universitas Pasundan Press.

Tahir, A. (2011). Kebijakan Publik dan Transparansi Penyelenggaraan Pemerintah Daerah. Jakarta. PT. Pustaka Indonesia Press.

Widjaja, H.A.W. (2002). Otonomi Daerah Dan Daerah Otonomi. Jakarta: PT.Raja Grafindo Persada. 